\title{
Mirjana Borenović
}

\section{René Girard's Scapegoating and Stereotypes of Perse- cution in the Divine Battle between Veles and Perun}

\section{Mehanizem grešnega kozla pri Renéju Girardu in pre- ganjanje $v$ božanskem boju med Velesom in Perunom}

Abstract: This paper describes René Girard's interpretation of myths and explains the scapegoating mechanism. This interpretation is then applied to the Slavic basic myth of the divine battle between Veles and Perun. The paper demonstrates that the myth of divine battle still holds enough information to identify and analyse the scapegoating mechanism, all the stereotypes of persecution, an innocent victim or the scapegoat and the violence committed against him. The analysis emphasises and decodes the process in which a human victim of persecution was transformed into a mighty god Veles. The paper also critically evaluates and points out the shortcomings of René Girard's interpretation of myths in the context of Slavic religion and mythology.

Keywords: stereotypes, persecution, Slavic mythology, Veles, Perun, scapegoating, mythology

Poværetek: Članek opisuje interpretacijo mitov pri Renéju Girardu in pojasnjuje mehanizem grešnega kozla. Ta interpretacija je zatem aplicirana na temeljni slovanski mit o božanskem boju med Velesom in Perunom. Članek prikazuje, kako je v mitu o božanskem boju še vedno dovolj informacij za identifikacijo in analizo mehanizma grešnega kozla, pa tudi vseh stereotipov preganjanja nedolžne žrtve oz. grešnega kozla in nasilja, ki se je nad njim izvajalo. Analiza poudarja in razlaga proces, v katerem se je človeška žrtev preganjanja preobrazila v mogočnega boga Velesa. Članek tudi izpostavlja in skuša kritično ovrednotiti primanjkljaje interpretacije mitov pri Renéju Girardu v kontekstu slovanske religije in mitologije.

Ključne besede: stereotipi, preganjanje, slovanska mitologija, Veles, Perun, mehanizem grešnega kozla, mitologija 


\section{Scapegoating and the stereotypes of persecution}

In his works, René Girard frequently discussed myth and used it as an example of overlooked persecution and collective violence. He recognised that myths are usually placed on the opposite side than history and are not read historically, since they are understood as belonging to a transcendent and religious plane. Girard disagreed with this kind of thinking because through his research, he came to realize that history as well as myth indirectly or directly describe persecution and collective violence. ${ }^{1} \mathrm{He}$ explained that the main reason for this unjustified distinction is an assumption that myths lack historical certainty that would redirect the reader to a different understanding and enable them to recognise the real and overlooked violence. The absence of necessary historical documents and an inability to decode the available texts (Girard 2011, 47-48) are two major reasons why persecution and collective violence are repeatedly overlooked in myths, by professional researchers of mythology (ethnologists and anthropologists) and amateur researchers alike.

Girard went even further by saying that not only is the myth always a narrative about persecution, but it is also a narrative about a real persecution and a real victim: "By proceeding from easy to more difficult, I intend to show that all myths must have their roots in real acts of violence against real victims" (Girard 1989, 25). The victim that Girard talks about is a scapegoat who cannot express their own innocence because they do not have their own voice in the myth and consequently cannot challenge the false accusations and prove their own innocence (2011, 61-66). It is important that just like historical persecution, historical (collective) violence and historical victims are examined and analysed from all angles and perspectives, myths should also be well researched and analysed from all perspectives. A written myth or an oral report must be observed for signs of a victim having the role of a scapegoat being present in the narrative. This can be achieved through the observation of specific characteristics: "Each time an oral or written testament mentions an act of violence that is directly or indirectly collective, we question whether it includes the description of a social and cultural crisis, that is, generalized loss of differences (the first stereotype), crimes that 'eliminate differences' (the second stereotype), and whether the identified culprits of these crimes are marked with signs that suggest a victim, the paradoxical marks of the absence of difference (the third stereotype). The fourth stereotype is violence itself, which will be discussed later" $(1989,24)$. Not all stereotypes need to be recognised in one narrative, because finding even a few of them reveals the objective nature of crisis, persecution, violence, false accusation and an

\footnotetext{
All the violence that is present in the scapegoating mechanism comes from one source - mimetic desire and rivalry. René Girard discovered that a person needs another person to understand what they want by mimicking the other person and competing for the same object they both desire to possess. "Violence is generated by this process; or rather violence in the process itself when two or more partners try to prevent one another from appropriating the object they all desire through physical or other means" (Girard 1996, 9). Mimetic rivalry can spread to an entire group and transform a community into a mob-like mass. This is a phase of acute disorder that causes a crisis in the community out of which the need for scapegoating arises. (12)
} 
intent to place the responsibility for the crisis on the victim and to banish or destroy them $(2011,47)$. The persecutors justify their actions with the hope that if they remove the victim that is allegedly responsible for the crisis, they consequently also remove the crisis itself.

The stereotypes that transform the victim into a scapegoat for the mob-like masses are described below.

René Girard $(2011,47)$ stated that the first stereotype is a description of a social and cultural crisis. ${ }^{2}$ Without a crisis, there would be no need to find or create a scapegoat and assign the responsibility for the ongoing crisis to them. The cause for a crisis can be external (epidemics, severe droughts, earthquakes etc.) or internal (political or religious instability). However, regardless of what circumstances trigger great collective persecutions, the experience of those who live through them is the same: "The strongest impression is without question an extreme loss of social order evidenced by the disappearance of the rules and 'differences' that define cultural divisions" $(1989,12)$. Communities and entire countries experience feelings of helplessness, uncertainty and chaos. Girard $(2011,66)$ explained that persecution as a mechanism was used to decrease fear and frustration levels caused by the crisis and redirected them against the victims - scapegoats.

The next stereotype that is distinctive for persecutions and frequently present in myths is the accusation including particular categories of crimes. At first, the accusations look fairly diverse, but at a closer look shows that they share some characteristics. The scapegoat is accused of crimes that are fundamental, because they attack the very foundations of cultural order. This particular category of crimes includes: crimes committed against the people that the masses believe should not be endangered in any situation (like kings, fathers, children, the innocent or the helpless). Sexual crimes, taboos and religious crimes are also a part of stereotypical accusations (Girard 1989, 14-15).

The third stereotype represents special signs for the selection of victims or simply victim's characteristics. René Girard claimed that the masses ${ }^{3}$ can randomly

Collective persecutions are frequent in times of crisis when institutions grow weak. This activates the masses and causes mob formation that can negatively affect the work of institutions and can even replace them (Girard 2011, 35).

3 In Girard's interpretation of myths, the mob-like mass is the one who is looking for a person to blame, who is violent and who wants to destroy the scapegoat in order to cleanse the society of the scapegoat's negative influence. In the minds of the persecutors, this needs to be done thoroughly because even one or two of the accused can threaten the cultural foundations of the community (Girard 2011, 38-39). The masses have no doubt that the person accused of horrible crimes is indeed guilty of all the charges. Girard $(2011,65)$ talked about the persecutors' true conviction that leaves no doubt of the scapegoat's guilt. The persecutors are not consciously aware they are a part of a scapegoating mechanism and do not recognise the innocence of the victim, because the main characteristic of scapegoating is its unconscious nature. (148) As we mentioned, during historical persecution as well as in the myth (in a form of a written or oral tradition), the innocence of the victim is not recognised. René Girard affirmed James George Frazer when he demonstrated the similarities between Christianity and myths, because in both cases the entire community kills the victim that later becomes a deity. But Girard also believed that Frazer overlooked an important element that proves how Christianity is different from mythology. By Girard's opinion, Christianity was the first religion in the world that clearly stated that Jesus Christ (victim/scapegoat) is innocent (Hoffman 2012). This biblical tendency to "side with the victim" can also 
choose a victim but that is usually not the case. In most cases, the victims possess the following special signs that make them especially vulnerable to persecution: belonging to ethnic or religious minorities, disability or any other characteristic that distinguishes a person from others, as well as any social abnormality (Girard 2011, 41). The chosen victims (pharmakos) were often people either on the outside or on the fringes of society: prisoners of war, slaves, foreigners or enemies and sometimes even children that have not yet undergone the rites of initiation or very old people that were not fully integrated into a society. The degree of integration into a society was a key factor for choosing a victim because the perfect scapegoat was someone who is basically an outsider and whom no one would miss or avenge. ${ }^{4}$ Sacrifice needed to be risk-free or "an act of violence without the risk of violence" $(2013,13-14)$. Possession of these characteristics is a decisive factor on which the mob-like masses decide that the chosen victim is truly guilty of the crime they are accused of. It is important to understand that the victim chosen to become a scapegoat is usually innocent, but they cannot prove their innocence because they do not have their own voice in the myth and consequently cannot challenge the false accusations and prove their own innocence. This is especially true in myths. Generally speaking, René Girard $(2011,41)$ was open to the possibility that the victim is really guilty of the crime they are being accused of but points out that their guilt is not primarily attributed to them because of the reality of their crime but rather because they possess the characteristics of a victim.

The last stereotype is the violence itself (Girard 2011, 47). Violence against the scapegoat mostly falls into the category of collective forms of violence (38). These are all forms of violence committed by the mob-like masses, including all forms of persecution and collective murder (95). Mob-like masses feel the need for violence against the scapegoat because they want to find the person responsible for the current crisis. ${ }^{5}$ They of course find the blame outside of themselves in an innocent person that is consequently transformed into a scapegoat (39) and collectively sacrificed and murdered. Girard $(2011,164)$ noted that the collective murder is actually a foundational murder, i.e. an essential core and origin from which the

be recognised in the Old Testament, where the biblical text (Gen 37:1-50:26) rejects the perspective of persecution and sees Joseph as an innocent scapegoat (Girard 2004, 17).

4 A chosen victim could also be someone who was well integrated in a society and possessed positive special talents or characteristics that others wanted for themselves. In this scenario, mimetic rivalry and competition caused disorder that called for the sacrifice of the scapegoat. No matter the starting positive characteristics of the victim-to-be, they are demonized in the scapegoating process, ascribed negative characteristics and accused of monstrous crimes.

5 The main characteristic of the mob-like mass and its individuals is their utter slavery to the mimetic desire that demands violence. Petkovšek $(2018,34)$ describes: "The archaic man could be saved from self-destruction, to which the whirlpool of violence led, only by the scapegoat mechanism - the sacrifice of an innocent." In spite of the reconciliatory effect of the sacrifice, the archaic man can only achieve freedom by waking up from his mimetic possession and starting living and acting consciously. Together with love and compassion, these are the building blocks of the "new man" that is free of slavery to the mimetic possession. 
myth is born. ${ }^{6}$ It is crucial to understand that collective murder is often covered up in mythology (105), which is why mentions of "voluntary self-sacrifice" (87) and individual violence that ends with the death of the victim should be treated with suspicion and precisely analysed (105). Girard claimed that collective murder was not removed from the texts that include older myths (117) because the coverup of collective murder is primarily a characteristic of newer mythological layers.

Paying attention to the stereotypes of persecution reveals that traces of persecution, collective violence and scapegoat's murder can be widely found in most of the world mythologies. ${ }^{7}$ It is natural to wonder what purpose does the sacrifice of the scapegoat serve. We have already partly answered our question when we described the persecutor's mindset: "If I destroy the victim that is allegedly responsible for the crisis, I consequently remove the crisis itself." The sacrifice of the scapegoat not only seemingly removes the crisis but also brings about reconciliation (improvement in relationships) and restoration of order, sometimes even on a higher level than before (Girard 2011,69). "The purpose of the sacrifice is to restore harmony to the community, to reinforce the social fabric" $(2013,9)$. This is because on a collective level, the act of sacrifice itself is liberating for the persecutors $(2011,69)$. For the sacrifice to have a liberating effect on the persecutors, they must not comprehend the true role of the sacrificial act. It is also important that they understand the sacrifice as a demand of the gods and/or ancestors for breaking the society's rule with an alleged unspeakable crime $(2013,7)$. There's an interesting logic in scapegoating that tries to fight violence caused by mimetic competition (and consequent crisis) with violence against the scapegoat (18-21). Because the scapegoat is expendable for the community, no one will avenge them and the cycle of violence in momentarily broken.

In myths, the power of reconciliation is attributed to the scapegoat (Girard $2008,81)$, who is understood as an active and all-powerful individual, while the

6 Many myths clearly state that the foundational murder is the starting point out of which culture and religion are born. In Sumerian mythology, the cultural institutions were created out of the bodies of gods like Ea, Tiamat and Kingu. A similar belief can be found in India, where the sacrifice of the cosmic man Purusha gave birth to the Hindu caste system. A Norse parallel to Purusha is a primordial being called Ymir out of which the world was created (Girard 2006, 99).

7 In some myths, stereotypes of persecution are easily recognisable, in others they are much harder to recognise. In most cases, with a detailed analysis, stereotypes can be found in vague descriptions of situations and people that clearly went through an editorial process to cover up the real story of persecution. These kinds of myths usually start with a description of disappearance of the rules and differences that define cultural divisions (cosmic myths about how the world came to be or myths about later chaotic situations, etc.). In these cases, the clue that we are dealing with a stereotype is hidden in the description of a chaotic situation that is a sign of crisis (first stereotype) (Girard 2011, 55-61). This is the case in the Aztec myth that explains how the sun and the moon came to be. The humblest of the Aztec gods Nanahuatzin sacrificed himself in the fire to shine on earth as the sun, thus becoming the sun god (85-90). Another sign that we are dealing with a transformed stereotype and persecution is the presence of a mythical monster (third stereotype). In Greek mythology, the example of such covered up persecution can be found in the myth of Minotaur. The mention of a trickster god should also alert us that we are possibly dealing with a hidden persecution. One of the most well-known trickster gods is the Norse god Loki who is frequently blamed for various crimes and represents the powers of chaos and destruction (Fee 2001, 56-61). Recognising stereotypes of persecution in the myths is tricky and demands a more detailed analysis because myths underwent greater intentional and unintentional transformation than younger narratives about historical persecutions (Girard 2011, 55-61). 
mob-like mass is depicted (and also understands itself) as passive and completely under the scapegoat's power $(2011,70)$. Both in historical persecutions and in myths, the scapegoat is understood as guilty for the current crisis, but myths have a transformational quality that transforms the sacrificial victim, who was accused of breaking the order and the rules of society, into a divine founder of order itself (69). In myth, the scapegoat is transformed twice, first into a personification of evil that is destroying the foundations of culture, and the second time, after the sacrifice and its effect of reconciliation, into a positive and benevolent force that restores and heals ${ }^{8}$ all the relations in a society. After the sacrifice, a human scapegoat in transformed into an immortal deity whom the masses worship. It is not uncommon that the transformed scapegoat becomes a patron deity against the misfortune and disaster that caused their sacrifice in the first place $(2008,81)$.

\section{The Divine Battle between Veles and Perun}

The gods Veles ${ }^{9}$ and Perun ${ }^{10}$ belong to the highest mythological ranks (Ovsec 1991, 118 ) because of their rule over the cosmological spheres and ancient origin. Both are found in one of the most important and well-known reconstruction of the myth that describes the divine battle between these two eternal opponents and represents the basic myth of Slavic mythology. The divine battle between Veles and Perun can be observed in a reconstruction of the myth that we will analyse through the perspective of Girard's scapegoating mechanism.

Mikhailov (2002, 58-60) summarized Ivanov's and Toporov's reconstruction ${ }^{11}$ of the basic myth by describing that the thunder god Perun, who dwells in the sky on the top of a mountain, persecutes his enemy, who has the form of a snake and lives below on earth. The reason for their conflict is that Veles stole cattle and people, as well as the Thunderer's wife in some versions of the story. The persecuted Veles hides under a tree and under a rock and transforms himself into a human, a horse and a cow. During the conflict with Veles, Perun splits the tree and the rock, throwing lightning. The victory ends with rain that promises fertili-

8 The act of sacrifice only has a positive effect on relations among people (internal causes) that the crisis deteriorated, but myths give an impression that the sacrifice also removes any external causes of the crisis, such as epidemics, natural disasters and wars (Girard 2011, 70).

9 Veles or Volos is frequently described as a god of cattle and other animals, but also as a god of abundance and wealth. He is a chthonic deity and can be understood as the god of the dead or the Lord of the Dead (Ovsec 1991, 119-120).

10 Perun is a god of thunder and lightning (the Thunderer). In $10^{\text {th }}$ century Kiev, he was depicted as a person with a golden moustache and a silver beard (Mikhailov 2002, 30). He is probably the highest-ranking god, but definitely the most known and worshiped all across the Slavic lands. Perun shares a lot of similarities with the Lithuanian god Perkūnas (113), based on which we can assume that Perun was also responsible for fertility and has a major role in protecting the laws and maintaining justice. He was a patron of warriors and military campaigns (Ovsec 1991, 111-113).

11 The reconstruction of the basic myth which is also described as a "storm myth" or a "pre-Slavic duel between Thunderer and his opponent" was done by two Soviet linguists, Vjačeslav V. Ivanov and Vladimir Toporov, based on outer (Baltic and Vedic mythology) and inner sources (mainly Belarussian fairy tales) (Toporov 2002, 34; Meletinsky 2013, 114). 
ty. Based on the Slavic ritualistic and mythological story-telling, Katičić $(2008,142)$ concludes that the thunder god Perun kills his opponent the dragon, who is a beast and a bear, and consequently liberates the rain which his opponent was withholding. Katičić also adds that the liberation of rain brings about a momentary danger of floods, but harmony is re-established in the end. Because the basic myth of the divine battle between Veles and Perun is Proto-Slavic, echoes of this motif are found in mythologies of all Slavic nations. In Slovenian mythology, this motif is preserved in a mythological being and hero Kresnik ${ }^{12}$ who battles his chthonic snakelike enemy (Mikhailov 2002, 59-61) and in the Slavic folk songs, including those from the Balkan area, in which the divine battle between Veles and Perun is set on the world tree (Katičić 2008, 105). ${ }^{13}$

The Slavic folk tradition says that a bird of prey sits on the top of the world tree, bees live in the middle and the hawk's enemy dwells at the bottom in the form of a dragon or a snake (Katičić 2008,76$)$. The bird of prey (a hawk or an eagle) who rules on the top of the world tree in none other than the divine Thunderer (79), whom the Slavs name Perun (105). The traditional folk songs describe Thunderer sitting on the top of the world tree and defending himself from his opponent who is attacking him from below, out of the roots of the world tree (136). Traditional songs sometimes mention that the snake threatens both Perun and his family (48). In the end, Perun wins the divine battle and defeats Veles (the snake).

Ethnologists and anthropologists classify the myth of divine battle between Veles and Perun as a storm myth (Ovsec 1991, 118) that our ancestors used to explain the turning of seasons and periods of drought and plentiful rain (Lyle 2009, 147). Girard of course did not agree with such explanations because he was convinced that at the core of myths, there is a hidden story of persecution which is repeatedly overlooked by anthropologists and ethnologists. While analysing the myth of divine battle through the eyes of René Girard, we found traces of all the stereotypes of persecution.

The first stereotype that enables the cycle of persecution to begin is the crisis. The myth of divine battle has a short description of the crisis, but it is not detailed or emphasized. It is also harder to recognise the crisis because the myth of divine

12 The battle between Veles and Perun and between Kresnik and his snakelike enemy are connected with a common motif. In addition to that, the etymologies of the words Perun and Kresnik share a common meaning. The root of the word Kresnik (Slovenian: "kres") is connected to the word "fire" (bonfire is "kres" in Slovenian) but also to the words "hitting" and "striking" ("kresniti" means to strike someone in Slovenian). Both of these meanings correspond to the characteristics of Perun who strikes with fire/ lightning. The root of the word Perun ("per") also means hitting, Perun is therefore someone who hits. In Slovenian, this root's meaning is preserved in a word "perem" which translates as "I wash" and describes the act of handwashing the laundry that was done by hitting the clothes during the washing process (Mikhailov 2002, 61; Ovsec 1991, 114).

13 Trees were important in the ancient Slavic religion. They represented a miniature image of the entire world and enabled a connection with the gods, the great beyond and the ancestors. A tree was not an object of worship itself but because of its characteristics. It expressed a middle point or the centre of the world and enabled a connection between the underworld, the earth and the heavenly sphere. A tree with such characteristics was worshiped as holy. This religious concept is called a world tree or axis mundi (Petrič 2018, $156-166$ ). 
battle is set in the sphere of the gods where we do not expect to find human models of behaviour. The myth of the divine battle says that the primary cause for the crisis was drought, but this is revealed only at the very end of the myth, where it is stated that after Perun's victory, rain began to fall, bringing fertility and hope (Ovsec 1991, 119). We can assume that in the ancient times, there was a long and deadly period of drought, which eventually caused starvation, sickness and death among people, animals and vegetation. Drought as a cause for crisis falls into the category of external causes and is accompanied by chaos and a loss of rule and social structure (Girard 2011,35). In the myth of divine battle, this is demonstrated when the snake (god Veles) tries to reach the top of the world tree and enter the heavenly sphere that is not under his rule. ${ }^{14}$ The fact that Veles overreached his ruling sphere reveals the disappearance of rules and differences that define cultural divisions and hold the society in an orderly and harmonious state. During this crisis, some people, including Veles, overreached their authority and interfered into the spheres that were not originally under their power. Together with a deadly drought, this must have caused an even greater uncertainty and fear among the mob-like mass.

The second stereotype is a "special kind of crimes" that are generally understood as threatening to the cultural foundations (Girard 2011, 38). The myth of the divine battle accuses Veles of these crimes but there is no consistency in what exactly he is accused of. Varieties of myth accuse him of stealing cattle or kidnapping people or kidnapping Perun's wife (Ovsec 1991, 118). Traditional Slavic folk songs accuse him of attacking Perun himself and/or his family (Katičić 2008, 136). Veles was accused of stealing cattle during a period of drought which results in starvation and possible death in community. It is a serious allegation of threatening the lives of people in the community. Veles was therefore blamed for crimes involving the worst boundary violations, such as perpetrating the most unthinkable attacks (Girard 2011, 38) on the king-like god Perun, on his children and - by stealing cattle - also on defenceless members of the community. The kidnapping of Perun's children, wife and unnamed members of the community also falls into the category of special kind of crimes. A common denominator of accusations made against Veles is an attack on the family that represents the cultural and societal foundations. The kidnapping of Perun's wife could also indicate the allegations of distinction-blurring sex crimes, most likely rape. While analysing the myth through Girard's eyes, we cannot help but be suspicious about the variety of allegations made against Veles. It seems that all the charges only serve to cover the basis allegation - Veles was recognised as guilty of holding back water and responsible for the drought. This theory is confirmed when after the battle, rain finally starts to fall and there is no description of the return of Perun's wife, children, members of community and cattle. It is clear that the persecutors blamed Veles for the drought and punished him for it.

We have discovered that in the context of surrogate-victim mechanism, Veles

14 Veles is a chthonic deity that mainly rules the underworld (Ovsec 1991, 120). 
was a scapegoat blamed for the long-lasting period of drought. René Girard believed that the victim/scapegoat is usually chosen for a reason (not randomly) and that there are certain criteria for choosing the victims. A scapegoat must have special characteristics for the selection of victims (third stereotype) that make them especially suitable for persecution (Girard 2011, 41). According to the description of Slavic folk tradition, Veles was a very suitable scapegoat, because he is described as being monstrous. Slavs imagined him as a hairy angry beast (Katičić 2008, 153), he was also described as a demon (142) or an evil spirit (Ovsec 1991, 120) in the Czech Republic. In his animalistic form, Veles appeared as an animal or mythological being that threatened the safety of human communities. These animals and mythological beings were a snake (Katičić 2008, 72), a bear (142), a wolf (Mencej 2001a, 159) and a dragon (Katičić 2008, 142). In his human form, Veles walks the earth as a Master of the Wolves or the Shepherd of the Wolves. He takes on the form of an old man (Mencej 2001a, 159) with a distinctive limp (2001b, 137). By using Slavic traditional folk descriptions of Veles, we recognised many special signs for selection of victims, such as his different physical appearance (described in Slavic folk tradition as monstrous and beastly), his disability (limping), his aggressive nature that represents a danger to the human communities and his trickster-like nature. In Slavic mythology, Veles takes on different divine roles, one of them being the role of a trickster god (Sherman 2015, 420). Despite their divine status, Girard $(2011,113)$ emphasized that trickster gods were only victims charged of monstrous crimes and subjected to persecution. With three clear characteristics of a victim, Veles was a very suitable candidate for a scapegoat. But there is one more possible special sign for the selection of victims that we should mention, even if there is no certainty about it. The person that after many mythological transformations became god Veles could have belonged to a religious or ethnic minority that existed in the time of Indo-Aryans. ${ }^{15}$ Because of their difference, individuals from ethnic and religious minorities were frequently chosen as scapegoats and consequently persecuted for alleged crimes (41). Being different seems to be a decisive factor on which mob-like masses unconsciously choose the scapegoat. Unusual as Veles was, he must have made a very convincing scapegoat.

The last stereotype that proves without a doubt that a certain myth is founded on the scapegoating mechanism is the violence itself (Girard 2011, 47). In the

15 It is commonly accepted that the Slavic mythology is layered on the top of an even older layer of Indo-European religion and mythology that is partly and with some differences written down in the Vedas. There are many similarities between the Slavic and the Vedic mythology, the content of myths and the names of the gods are usually comparable. In Slavic mythology, we have a divine battle between Veles and Perun, and in the Rigvedas, there is a divine battle between Vritra and Indra. Vritra is the demon of drought, described as a serpent or a dragon that blocks the course of rivers. God Indra defeats his enemy Vritra, kills him and releases the waters (Shendge 1977, 50). One of many interpretations of this myth claims that before Indra was a god, he used to be an Aryan conqueror, and before Vritra was a demon, he used to be a native settler of the Indo-Gangetic plain. Both experienced a transformation through the scapegoating mechanism. Indra transformed into a glorious god and Virtra was demonized together with his entire ethnic and religious community, but still gained a supernatural status (280). Because the Slavic divine battle between Veles and Perun is connected to the Vedic divine battle between Vritra and Indra, we should consider that the primary scapegoat lived in the time of Indo-Aryan migration to the Indian subcontinent. 
myth of the divine battle between Veles and Perun, persecution and violence are clearly recorded. When Veles was accused and found guilty of holding back the water and causing drought, Perun ruthlessly attacked him. Veles ran from him and hid, but Perun overpowered him at the end and destroyed him (Ovsec 1991, 118). It should not surprise us that the element of collective violence is absent in the myth (persecution and destruction is done by Perun alone), because according to Girard $(2011,107)$, mythology strives to erase any traces of collective violence by substituting it with individual violence (Perun's violence) (107). On the basis of scapegoating mechanism, we can assume that Veles was originally accused, persecuted and murdered by the entire community, but over time, oral tradition changed the story so that the collective violence was replaced by individual violence.

The mechanism ends with the sacrifice of the scapegoat (Veles), who brought together the entire community in their hatred against the common enemy. Sacrifice caused the improvement of relations in the community, which was in crisis because of the drought. The myth reports that around the time of the sacrifice, rain started to fall, which transformed a human scapegoat into the worshiped god Veles, and the sacrifice itself into a basic myth. In this process, Veles was transformed twice.: He was first demonised and falsely accused of causing the drought and threatening the community's existence. His second transformation occurred after the sacrifice and elevated him into a deity that could protect its worshippers against the dangers he was originally accused of while still human. According to the Slavic tradition, the scapegoat became the god of cattle and other animals, consequently also of abundance and wealth (Ovsec 1991, 119). Today we know Veles as a chthonic deity, a Lord of the Underworld (120) who ruled the dead in a land across the great river or the sea (250). He is especially connected with the underground waters. After the second transformation, everything he was accused of became a part of his divinity.

\section{Conclusion}

In this paper, we examined the myth of a divine battle between Veles and Perun through the eyes of René Girard and demonstrated that there is still enough information in the myth to identify the stereotypes of persecution, (collective) violence and murder. All the violence is directed at Veles who is an innocent victim and a scapegoat for the mob-like masses. We discovered that an official reason for the crisis was a long-lasting drought, but the true cause for violence and persecution could have been a mimetic rivalry that poisoned the entire community. We also identified sexual crimes and crimes against family and community that Veles was accused of and Veles' specific characteristics that made him an especially suitable scapegoat, including his beastly appearance, violent nature, disability and trickster-like nature. The myth ends with Veles' destruction and transformation from an innocent human to a powerful god. 
Girard was convinced that the foundational violent event of the myth really happened: "Myths represent persecutions similar to those we have interpreted, but they are more difficult to decode because they contain distortions. The transfigurations are stronger in mythology. The victims become monstrous and display fantastic power. After sowing disorder, they re-establish order and become the founding fathers or gods" (Girard 1989, 54). We could ask ourselves who came first, humanity or the gods? Girard's answer would be: "Humanity!" On the timeline of religions, this worldview places humankind before the birth of the gods and consequently overlooks an important fact expressed by Jonathan Kirsch (2004, 1) that something deep in human nature prompts us to imagine the existence of a power greater than ourselves. In different religions, these powers had their own names and characteristics, but they all shared a common trait - people imagined they existed long before our kind. Karen Armstrong $(1999,3)$ similarly talks about human beings as spiritual animals and argues that: "Homo sapiens is also Homo religiosus. Men and women started to worship gods as soon as they became recognizably human; they created religions at the same time as they created works of art." Both authors emphasize that humanity evolved together with its need, ability and practice of spirituality. Recent research in the field of archaeology confirms that the capability for symbolic thought as a precondition for spirituality was not limited to Homo sapiens (Than 2013). Wunn (2000, 417-452) explains that the origin and the development of religious feeling should be traced back to the middle Palaeolithic period, to the time of Homo neanderthalensis as an early representative of the genus Homo who has already developed advanced intellectual abilities and the beginnings of religious belief in the form of existence after death, which was expressed by conscious burials of the deceased.

Archaeological findings suggest that there is no "one origin" of religion or gods but only a gradual process of growing capability for religious beliefs that involved both species of the genus Homo. This perspective challenges Girard's claims that there exists a starting point of religion and that only one violent event (foundational murder) gave birth to a specific god. In his works, Girard claimed that myths are transformed historical persecutions and that other sciences (history, ethnology, anthropology etc.) overlooked their historical element - its realness. At the same time, he himself fails to place historical persecutions in a tangible timeframe and to answer the following questions: When did the first foundational murder happen? Which species committed it (both Homo sapiens and Homo neanderthalensis were capable of religious beliefs and the conflict between them could possibly be the first and largest historical persecution)? Are we talking about a series of foundational murders or just one that was retold in different mythologies?

The last question is especially significant for our research because Slavic mythology is closely connected to the Proto-Indo-European mythology out of which it grew and consequently also to the Vedic mythology. One of the important mythological elements of the Proto-Indo-European religion is the dragon-slaying myth. The younger version of this myth is written down in the Vedas as a battle between Indra and Vritra and retold in the Slavic myth of the divine battle between Ve- 
les and Perun. The Vedic and Slavic dragon-slaying myths share very similar storylines and linguistic similarities. It is wise to ask ourselves: "How many times did the foundational murder happen?" Three times (once on the Proto-Indo-European level, once on the Vedic level and once on the Slavic level) or just once in the time of Proto-Indo-Europeans or even earlier in history? If every myth contains a transformed historical persecution (first interpretation), as Girard claimed, then we're dealing with a multitude of victims, separate persecutions and independent deities that all share common traits. This interpretation treats mythologies that grew out of the Proto-Indo-European mythology as separate and independent of one another, completely overlooking their common origin. If the second interpretation is correct and only one foundational murder happened, transforming the scapegoat into a god, and the myth was then retold through the ages, causing the non-sacrificial creation of similar gods in different mythologies, then another question arises: "When did the first foundational murder happen and who were the people involved? The easy answer would be: "Proto-Indo-Europeans that lived during the late Neolithic, or roughly the 4th millennium BC or earlier." But it is unclear how the Proto-Indo-European religion evolved, which religious elements are uniquely Proto-Indo-European and which were possibly adopted from other religious and cultural sources. Answering the question of "When?" would demand a greater knowledge of ancient cultures and religions than is currently available to us.

In the context of the divine battle between Veles and Perun, and the birth of the god Veles, Girard's theory offers two interpretations. First and most literal is that there existed a human victim that was transformed into a god after they were sacrificed during the scapegoating. Second and more intangible interpretation is that a very long time ago, at the time of the Proto-Indo-Europeans or even before that, there existed a man that was sacrificed and transformed into a god. His story, captured in a myth, was retold over generations and found its place in mythologies of the Indo-European origin.

René Girard $(2006,85)$ also believed that people do not just create their gods but transform their victims into deities. For him, all mythology, including the Slavic mythology, was a deceptive human construct (15). This human-oriented interpretation of world mythologies is partly problematic because it does not recognise the sacredness of nature which is the core belief of all ancient ethnic polytheistic religions around the world. Slavic gods represent aspects of nature in its immanent and transcendent form and could therefore not be narrowed down to a mere deification of the victim. If we consistently adhere to Girard's theory, we would have to admit that at some stage of existence, humanity was completely atheistic. The same should also apply to the Slavs, who had at a specific and unknown moment in time unconsciously created their first god through the scapegoating mechanism. Nature and her aspects cannot simply be human victims transformed into gods because that would mean that during the humanity's atheistic period, nature was not perceived as having divine attributes, but after the scapegoating mechanism and creation of a god connected with the natural envi- 
ronment, this perception changed to the point where nature became sacred. It is very unlikely that this shift happened because claiming that an atheistic period existed in human history is in direct contrast to the archaeological findings that clearly speak of early traces of spirituality expressed in cave art, richly decorated artefacts, ancient burial traditions (including Slavic burial traditions) etc., which all have clear mythological motifs and patterns of flora and fauna.

The second reason why nature and her aspects cannot simply be human victims transformed into gods is because in Slavic mythology, nature is distinguishable from people and human communities. The otherness, wilderness and invincibility are an important part of the sacredness of nature but even more essential is her relational aspect. In Slavic religion, nature and her aspects consisting of flora, fauna and inanimate nature are the Other with which an individual can communicate and expect (sometimes miraculous) response. The act of establishing a relationship with nature and communicating with it (understanding that Slavic gods are aspects of nature) demands that humanity opens up to the Other. Only in this context, the worship of something outside of ourselves is possible. For the ancient Slavs, the natural environment was what was outside of them and called to worship. Girard's theory is the opposite of this model - it suggests that humanity did not find and establish relationships with the gods outside of themselves but created them. Gods are a product of mimetic crisis (human crisis) that needed to end in order for a specific human community to survive (human need), which is why the community sacrificed one of its own (human victim) and assigned them supernatural abilities (human activity). A god was born and the human community reached a higher state of peace, order and togetherness (human benefit). In Girard's theory, there is no place for the Other that is being worshipped and human spirituality is completely self-sufficient, self-serving and closed off from nature in a relational way. That is why people in Girard's theory do not feel the need to establish worship-based relationships with the nature, causing a lack of the element of wonder and connectedness that comes with being in touch with something greater than ourselves. As Armstrong $(1999,3)$ puts it: "This was not simply because they wanted to propitiate powerful forces, but these early faiths expressed the wonder and mystery that seems always to have been an essential component of the human experience of this beautiful yet terrifying world. Like art, religion has been an attempt to find meaning and value in life, despite the suffering that flesh is heir to."

When analysing myths through the eyes of René Girard, one has to admit that stereotypes of persecution can be found practically in every myth. This was also the case in the Slavic myth of the divine battle between Veles and Perun. On a theoretical level, Girard's theory has a lot to teach us about the structure of myths, but on a practical level, it fails to give us the answers about "Who?", "When" and "How many times?" concerning foundational murder. It also fails to recognise the basic differences between polytheisms and monotheisms, and that nature worship was an important distinguishable element between the two. Another shortcoming of the theory is that it fails to connect and create a constructive dialogue 
with other sciences, especially with archaeology, history, theology, anthropology and ethnology. Only cooperation between the mentioned sciences could provide enough information to start answering the questions of the origins of myths, religions and the gods.

\section{References}

Armstrong, Karen. 1999. A History of God. From Abraham to the Present: the 4000-year Quest for God. London: Vintage Books.

Fee, Christopher R. 2001. Gods, Heroes, and Kings: The Battle for Mythic Britain. Oxford: Oxford University Press.

Girard, René. 2013. Violence and the Sacred. Trans. Patrick Gregory. London: Bloomsbury.

- - -. 2011. Grešni kozel. Znanstvena knjižnica 25. Trans. Slavica Jesenovec Petrović and Borut Petrović Jesenovec. Ljubljana: Teološka fakulteta Univerze v Ljubljani.

-- -. 2006. Gledam satana, ki kakor blisk pada z neba. Trans. Vesna Velkovrh Bukilica. Ljubljana: KUD Logos.

- - - 2004. The Girard Reader. Ed. James G. Williams. New York: The Crossroad Publishing Company.

- - . 1989. The Scapegoat. Trans. Yvonne Freccero. Baltimore: The Johns Hopkins University Press.

Hoffman, Jana. 2014. Rene Girard: Is Christianity a Myth? $10^{\text {th }}$ of November. https://youtu.be/ iQSJeDFelYU (accessed $24^{\text {th }}$ of March 2019).

Katičić, Radoslav. 2008. Božanski boj: Tragovima svetih pjesama naše pretkršćanske starine. Zagreb: Katedra Čakavskog sabora Općine Mošćenička Draga Odsjek za etnologiju i kulturnu antropologiju Filozofskog fakulteta Sveučilišta u Zagrebu.

Kirsch, Jonathan. 2004. God Against the Gods: The History of the War Between Monotheism and Polytheism. New York: Penguin Compass.

Lyle, Emily. 2009. Indo-European Time and the Perun-Veles Combat. Studia mythologica Slavica 12:147-152.

Matasović, Ranko. 2018. A Reader in Comparative Indo-European Religion. $10^{\text {th }}$ of December. http://mudrac.ffzg.unizg.hr/ rmatasov/PIE\%20 Religion.pdf (accessed $22^{\text {nd }}$ of November 2019).

Meletinsky, Eleazar M. 2013. The Poetics of Myth. Theorists of myth 9. Trans. Guy Lanoue and Alexandre Sadetsky. New York: Routledge.

Mencej, Mirjam. 2001a. Volčji pastir v kontekstu dosedanjih raziskav na področju slovanske mitologije. Studia mythologica Slavica 4:159187.

- - - 2001b. Gospodar volkov v slovanski mitologiji. Županičeva knjižnica nu. 6. Ljubljana: Filozofska fakulteta oddelek za etnologijo in kulturno antropologijo.

Mikhailov, Nikolai. 2002. Mythologia slovenica: poskus rekonstrukcije slovenskega poganskega izročila. Trst: Mladika.

Ovsec, Damjan J. 1991. Slovanska mitologija in verovanje. Zbirka Sopotja. Ljubljana: Domus.

Petkovšek, Robert. 2018. Svoboda med žrtvovanjem in darovanjem. Bogoslovni vestnik 78, No. 1:33-51.

Petrič, Nejc. 2018. Axis mundi na primeru drevesa v izročilu Zahodne Slovenije. In: Nejc Petrič and Marko Hren, ed. Pozno pokristjanjevanje slovenskega ozemlja, 155-172. Zbornik prispevkov predstavljenih na simpoziju, Kobarid, 12.8.2017. Ljubljana: Društvo Slovenski staroverci.

Shendge, Malati J. 1977. The Civilized Demons: The Harrappans in Rigveda. New Delhi: Abhinav Publications.

Sherman, Josepha, ed. 2015. Storytelling: an encyclopedia of mythology and folklore. New York: Routledge.

Than, Ker. 2013. Neanderthal Burials Confirmed as Ancient Ritual. $16^{\text {th }}$ of December. https://www. nationalgeographic.com/ news/2013/12/131216-la-chapelle-neanderthal-burials-graves/ (accessed $22^{\text {nd }}$ of November 2019).

Toporov, Vladimir Nikolajevič. 2002. Predzgodovina književnosti pri Slovanih: poskus rekonstrukcije; Uvod v preučevanje zgodovine slovanskih književnosti. Zbirka Župančičeva knjižnica 9. Trans. Lijana Dejak. Ljubljana: Oddelek za etnologijo in kulturno antropologijo Filozofske fakultete.

Wunn, Ina. 2000. Beginning of Religion. Numen-International Review for The History of Religions 47:417-452. 